Available online:

IMLA

\title{
STRATEGI PEMBELAJAR INDONESIA MENGIDENTIFIKASI MAKNA KATA BAHASA ARAB DALAM KONTEKS KALIMAT WACANA GEOGRAFI
}

\author{
Imam Asrori \\ Universitas Negeri Malang \\ E-mail: imam.asrori.fs@um.ac.id
}

\begin{abstract}
This restrospective research studied the strategies employed by Indonesian students in identifiying the meaning of Arabic words in context. This study found: first, the students identified the word meaning using the following strategies: (a) using a billingual dictionaries (digital dictionary, printed dictionary, online dictionary), (b) asking friends, and (c) utilizing context. Second, students were able to identify the full context and identify the meaning of difficult words accurately. Third, relating meaningful context and accurate meaning which found four patterns of integrating context and accuracy of meaning, namely (a) full context and accurate meaning ( $F-A)$, (b) full context but innacurate meaning (F-NA), (c) incomplete context but accurate meaning (NF-A), and (d) incomplete context and inacurate meaning (NF-NA). The ability to identify full context tends to help students to identify the meaning of words accurately.
\end{abstract}

Keywords: strategy, Indonesian students, the meanings of words, Arabic, context

\begin{abstract}
Abstrak
Penelitian restrospeksi ini mengkaji strategi yang ditempuh pembelajar Indonesia dalam mengidentifikasi makna kata bahasa Arab dalam konteks. Hasil penelitian ini adalah: pertama, mahasiswa mengidentifikasi makna kata sulit dengan strategi (a) menggunakan kamus dua bahasa (kamus digital, kamus cetak, kamus online), (b) bertanya kepada teman, dan (c) memanfaatkan konteks. Kedua, mahasiswa memiliki kemampuan yang tinggi dalam mengidentifikasi konteks yang utuh dan mengidentifikasi makna kata sulit secara akurat. Ketiga, menghubungkan keutuhan konteks dan akurasi makna menghasilkan empat pola hubungan, yaitu (a) konteks utuh dan makna akurat (U-A), (b) konteks utuh tapi makna tidak akurat (U-TA), (c) konteks tidak utuh tapi makna akurat (TU-A), dan (d) konteks tidak utuh sekaligus makna tidak akurat(TU-TA). Kemampuan mengidentifikasi keutuhan konteks lebih mendukung dalam mengidentifikasi makna secara akurat.
\end{abstract}

Kata Kunci: strategi, pembelajar indonesia, makna kata, bahasa Arab, konteks 


\section{Arabi : Journal of Arabic Studies}

\section{Pendahuluan}

Kosakata (mufradat) merupakan salah satu komponen bahasa yang perlu dikuasai oleh pembelajar bahasa Arab dan bahasa asing (basing). Seorang pembelajar bahasa Arab dapat dengan mudah memahami isi teks yang dibaca atau disimak jika ia memiliki penguasaan kosakata yang memadai. Sebaliknya, jika perbendaharaan kata yang dimiliki terbatas, ia akan kesulitan memahami suatu teks bacaan/simaan. Demikian halnya dalam hal kemahiran menulis dan berbicara, penguasaan kosakata sangat diperlukan untuk dapat mengembangkan gagasan ke dalam teks lisan/tulis.

Kweldju (2002) mengutip hasil penelitian Medgyes (1994) bahwa kesulitan yang paling besar dihadapi oleh guru bahasa Inggris adalah kesulitan kosakata dibandingkan kesulitan di bidang tenses dengan perbandingan 42:5. Secara umum perbendaharaan kata yang dimiliki mahasiswa jurusan bahasa Inggris di Indonesia rata-rata hanya 15\%. Dari yang dimiliki mahasiswa penutur asli. Karena itu, komponen bahasa yang perlu mendapatkan prioritas utama dalam pengajaran menulis adalah kosakata dan diksi.

Dzulkifli dan Musthafa (2011) mengemukakan bahwa salah satu problem belajar-mengajar yang dihadapi oleh (maha)siswa BA adalah problem membaca teks BA yang disebabkan oleh minimnya penguasaan kosakata. Mahasiswa menghadapi banyak kata sulit yang tidak mereka pahami maknanya. Hal itu berdampak pada kesulitan memahami isi dari teks yang dibaca. Dengan kata lain, kurangnya penguasaan kosakata berdampak pada kesulitan memahami isi teks. Hal tersebut selaras dengan realitas pembelajaran BA di Universitas Negeri Malang (UM).

Dalam pembelajaran bahasa Arab di UM digunakan buku-buku ajar dan buku-buku referensi berbahasa Arab. Penggunaan buku-buku teks dan referensi berbahasa Arab tersebut tidak terbatas pada matakuliah kebahasaan dan keterampilan berbahasa, melainkan juga pada kelompok matakuliah non kemahiran berbahasa, baik kelompok matakuliah kesastraan, misalnya matakuliah Nushush a-Adab (apresiasi sastra) dan bahkan pada kelompok matakuliah kebudayaan, misalnya matakuliah Geografi Dunia Arab dan Islam. Ketika mengikuti perkuliahan dengan referensi berbahasa Arab, mahasiswa tampak mengalami kendala yang diakibatkan oleh kurangnya penguasaan kosakata BA. Kurangnya penguasaan kosakata bahasa Arab semakin tampak pada waktu mahasiswa membaca buku-buku referensi ataupun teks media masa, makalah, dan artikel.

Kinsella et al (2002) mengemukakan empat cara untuk mengembangkan kosakata, yaitu a) memanfaatkan kamus, b) menggunakannya dalam kalimat, c) memperhatikan konteks, dan d) menghafalkan definisi. Dari empat cara tersebut, dua cara untuk memperoleh atau mengidentifikasi makna kata baru, yaitu a) dan c) dan dua cara lainnya, yaitu b) dan d) untuk merawat kata yang telah diperoleh. Hal itu berarti keterampilan mengidentifikasi atau menemukan makna kata BA sangat penting untuk dikembangkan.

Hunt dan Beglar (2005) dalam tulisannya berjudul $A$ Framework for Developing EFL Reading Vocabulary mengemukakan atau menawarkan penggabungan dua pendekatan sekaligus dalam rangka pengembangan penguasaan kosakata. Dua pendekatan dimaksud adalah penerapan strategi belajar dan pengajaran kosakata secara eksplisit dan implisit sekaligus. Strategi belajar dan mengajar kosakata secara eksplisit meliputi tiga hal yaitu (a) memperoleh leksikal tanpa konteks, (b) menggunakan kamus, dan (c) menginferensi berdasarkan konteks. Di sisi lain, strategi belajar dan mengajar kosakata secara implisit antara lain dalam bentuk: (a) menggunakan seperangkat tugas secara integral dan membaca fokus (narrow). Karena itu, guru/dosen BA tidak saja perlu mengajarkan kosakata, melainkan juga perlu melatihkan strategi atau cara-cara tertentu untuk mengidentifikasi makna kata dalam konteks.

Bengeleil dan Paribakht (2004) melakukan penelitian berjudul L2 Reading Proficiency and Lexical Inferencing by University EFL Learners dengan tujuan untuk mengungkapkan efektivitas membaca dalam hubungannya dengan terka makna kosakata. Subjek penelitian mereka adalah mahasiswa Arab-Libia Fakultas Kedokteran yang sedang belajar bahasa Inggris dengan usia 22-25 tahun. Subyek terdiri atas 17 mahasiswa dari dua kelompok kemampuan membaca yang berbeda,

Vol. 1 No. $2 \mid 12-23$

Copyright @ 2016 | ARABI | p-ISSN 2548-6616 | e-ISSN 2548-6624 
yaitu 10 mahasiswa kelompok menengah dan 7 mahasiswa kelompok atas. Kepada subjek penelitian diberikan 26 soal kosa kata yang harus diidentifikasi maknanya dalam konteks. Bengeleil dan Paribakht menyimpulkan bahwa kedua kelompok menggunakan petunjuk-petunjuk konteks dan sumber kognitif/informasi yang sama dengan menyimpulkan makna kosakata. Dalam hal ini, kelompok menengah lebih bergantung kepada pengetahuan tentang asal kata.

Penelitian lain dilakukan oleh Nassaji (2003) dengan tujuan untuk mengungkapkan sumber pengetahuan dan pola strategi menerka makna kosakata (Mohebbi, 2013). Nassaji (2003) meneliti penggunaan strategi dan sumber pengetahuan dalam melakukan inferensi makna leksikal serta hubungannya dengan kesuksesan penggunaan strategi tersebut. Ia menemukan bahwa tingkat kesuksesan mereka rendah meskipun pembelajar B2 menerapkan strategis dan sumber pengetahuan yang dapat mereka akses. Mohebbi (2013) juga mengutip penelitian Nassaji lainnya (2004) yang meneliti hubungan kedalaman pengetahuan kosakata pembelajar B2 dan penggunaan strategi inferensi leksikal dan kesuksesannya. Ia menemukan bahwa pembelajar yang memiliki pengetahuan kosakata B2 yang lebih kuat cenderung lebih banyak menerapkan strategi infereksi leksikal tertentu. Ditemukan bahwa kedalaman pengetahuan kosakata B2 sangat penting dalam kesuksesan inferensi leksikal.

Penelitian terdahulu tersebut semuanya dalam konteks belajar bahasa Inggris. Dalam konteks belajar bahasa Arab, penelitian tentang strategi belajar pernah dilakukan oleh Asrori (2007) dengan judul Pengembangan Kemahiran Berbicara Bahasa Arab oleh Mahasiswa Penutur Bahasa Indonesia dalam Perspektif Strategi Belajar Bahasa (SBB). Penelitian tersebut lebih mengarah kepada penggunaan strategi belajar dalam konteks kemahiran berbicara bahasa Arab dan bukan pengembangan kosakata.

Karena itu, penelitian berjudul Strategi Mahasiswa Indonesia Mengidentifikasi Makna Kata Bahasa Arab dalam Konteks Kalimat Wacana Geografi ini penting untuk dilaksanakan sehingga diperoleh hasil kajian ilmiah tentang masalah tersebut. Penelitian ini memiliki beberapa kekhususan, yaitu dilakukan dalam konteks belajar kosakata bahasa Arab sebagai bahasa asing, subjek penelitian ini berbahasa ibu bahasa Indonesia, dan strategi belajar kosakata yang diteliti lebih bersifat umum, dalam arti tidak fokus pada strategi menerka makna. Penelitian ini bertujuan untuk mendeskripsikan: 1) strategi mahasiswa Indonesia dalam mengidentifikasi makna kata sulit bahasa Arab dalam konteks yang mencakup variasi strategi dan kecenderungan penggunaan strategi, 2) kemampuan mahasiswa mengidentifikasi keutuhan konteks dan akurasi makna, dan 3) pola hubungan penggunaan strategi, keutuhan konteks, dan akurasi makna.

Penelitian ini dilaksanakan dalam konteks perkuliahan Geografi Dunia Arab dan Islam (Geoduaris) di Jurusan Sastra Arab Universitas Negeri Malang yang diikuti oleh mahasiswa semester IV. Matakuliah ini merupakan salah satu dari tiga matakuliah kebudayaan di Jurusan Sastra Arab. Melalui matakuliah ini, mahasiswa mengenali aspek-aspek geografi, politik, dan budaya negara-negara Timur Tengah. Dalam perkuliahan ini digunakan bahan ajar berbahasa Arab dan secara umum digunakan bahasa Arab sebagai bahasa pengantar dan dengan bahan ajar berbahasa Arab pula.

\section{Metode Penelitian}

Penelitian ini menggunakan rancangan penelitian kuantitatif. Data penelitian berjumlah 617 kata sulit dilengkapi dengan (a) perilaku mahasiswa mengidentifikasi makna kata sulit bahasa Arab dalam konteks, (b) satuan kebahasaan yang diidentifikasi sebagai konteks yang mengandung kata sulit tersebut, dan (c) makna kata. Data diambil dari 57 mahasiswa peserta perkuliahan Geografi Dunia Arab dan Islam. Pengumpulan data dilakukan melalui retrospeksi, yaitu setiap pekan mahasiswa membaca materi perkuliahan berbahasa Arab dan melaporkan secara tertulis halhal berikut: a) minimal lima kosakata yang dianggap sulit dari bahan ajar tersebut, b) kalimat atau penggalan teks sebagai konteks kebahasaan yang utuh yang mewadahi kata sulit tersebut, c) makna kata sesuai yang dimaksud dalam konteks, dan d) strategi menemukan makna tersebut. 


\section{Arabi : Journal of Arabic Studies}

Mahasiswa mencatatkan data-data tersebut pada form yang telah ditentukan peneliti sehingga terdapat keseragaman pola.

Data yang diperoleh dianalisis secara kuantitatif dengan prosedur sebagai berikut: a) data perilaku/strategi belajar dianalisis dan dikelompokkan berdasarkan teori strategi belajar kosa kata kemudian dihitung persentase penggunaan setiap jenis strategi. Data satuan kebahasaan dianalisis berdasarkan teori klausa dan frasa dengan indikator keutuhan klausa tanpa adanya frasa yang menggantung. Data makna kata dianalisis akurasinya berdasarkan konteks kebahasaan atau konteks gramatik yang membungkus kata sulit yang dimaksud.

\section{Strategi Mengidentifikasi Makna Kata Sulit Bahasa Arab dalam Konteks}

Terdapat tiga strategi besar yang ditempuh mahasiswa dalam mengidentifikasi makna kata sulit dalam konteks, yaitu a) menggunakan sumber, b) bertanya kepada teman, dan c) memanfaatkan konteks. Sumber yang dimaksudkan adalah sumber belajar yang terdiri atas kamus cetak, kamus digital, dan kamus online (internet). Strategi bertanya kepada teman ditempuh ketika subjek tidak menemukan makna kata tersebut pada suatu sumber, atau untuk menemukan makna secara cepat. Adapun strategi konteks maksudnya adalah berusaha menemukan makna dengan menganalisis kata-kata yang melingkupinya dalam konteks kalimat. Dalam hal ini, subjek menebak makna suatu kata berdasarkan petunjuk-petunjuk sintaksis dan hubungan struktur ataupun hubungan makna antarkata yang membentuk suatu kalimat.

Variasi strategi belajar kosakata juga tampak pada variasi kamus cetak yang digunakan, yaitu kamus satu bahasa (Almawrid) dan delapan kamus dua bahasa (kamus Al-Qalam, Kamus AlAzhar, Kamus Al-Maurid, Kamus Kontemporer, Kamus Modern, kamus Al-Munawir, Kamus AlAli, Kamus Al-Bisri, dan Kamus Mahmud Yunus). Dari tiga jenis strategi tersebut, yang lebih dominan adalah strategi menggunakan sumber. Adapun dari tiga kategori kamus yang digunakan, kamus digital paling dominan digunakan. Secara keseluruhan, penggunaan kamus digital mendominasi keempat jenis strategi lainnya dengan urutan sebagaimana pada grafik 01 berikut, yaitu:

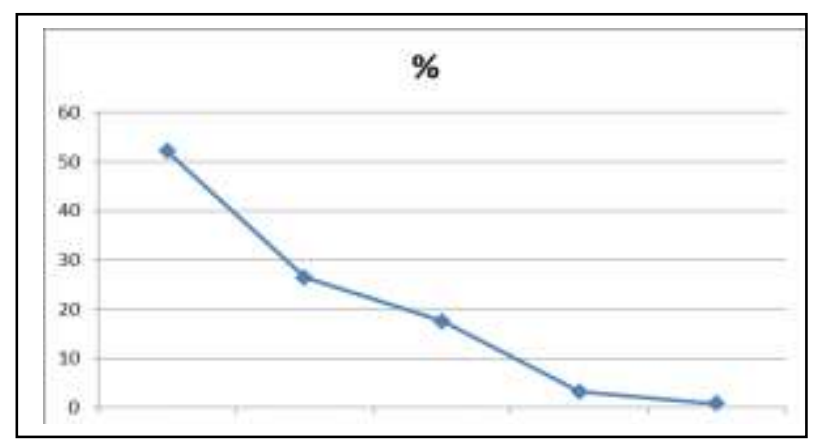

1) kamus digital $(52.03 \%)$,

2) kamus cetak $(26.42 \%)$,

3) kamus online (17.50\%),

4) bertanya kepada teman (3.24\%),

5) dan memanfaatkan konteks $(0.81 \%)$.

\section{Grafik 01: Urutan Frekuensi Penggunaan Strategi}

\section{Kemampuan Mengidentifikasi Konteks secara utuh dan Makna secara Akurat}

Yang dimaksud dengan konteks yang mengandung kata sulit adalah satuan kebahasaan yang mewadahi atau melingkupi suau kata sulit. Satuan kebahasaan tersebut dinilai utuh jika satuan yang diidentifikasi mahasiswa itu minimal berbentuk atau terdiri atas satu klausa dan mengandung unsur-unsur kelengkapan frasa. Sebaliknya, jika suatu satuan kebahasaan yang diidentifikasi mengandung kata sulit tersebut tidak membentuk klausa atau berupa klausa tetapi terdapat unsur kelengkapan frasa yang ditinggalkan, maka konteks yang dimaksudkan dinilai tidak utuh. Konsep keutuhan konteks ini sejalan dengan jenis konteks kalimat yang dikemukakan oleh Dash (2008).

Kemampuan mahasiswa mengidentifikasi konteks secara utuh relatif tinggi dengan skor 89.72 bagi mahasiswi dan 84.80 bagi mahasiswa (lihat grafik 02). Kemampuan mengidentifikasi makna dalam konteks secara akurat juga relatif tinggi baik bagi mahasiswi maupun mahasiswa dengan skor 72.59:70.61. Grafik 03 menyajikan proporsi akurasi makna pembelajar PA dan PI 
sekaligus perbandingan persentase makna yang akurat dan tak akurat. Untuk memberikan gambaran yang lebih riil, dikemukakan beberapa contoh konteks yang utuh dan yang tidak utuh hasil identifikasi mahasiswa. Contoh 1 dan 2 merupakan contoh konteks utuh dan contoh 3 dan 4 contoh konteks tidak utuh.

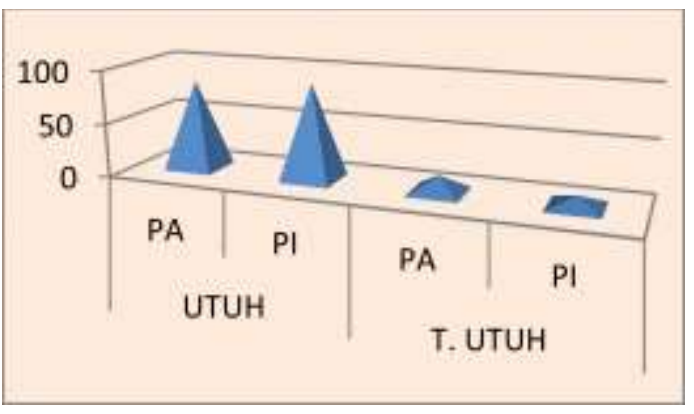

Grafik 02: Perbandingan Keutuhan Konteks

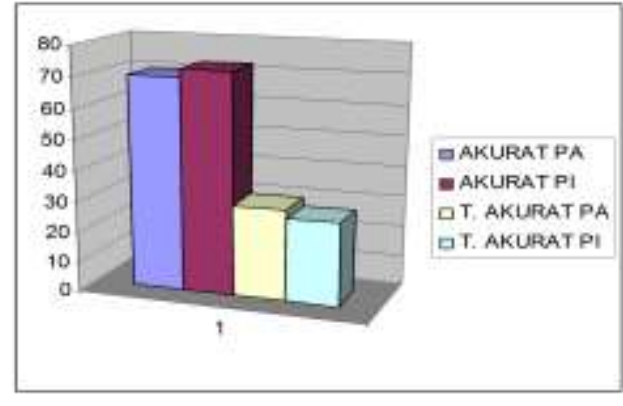

Grafiks 03: Proporsi akurasi makna PA dan PI

(1)

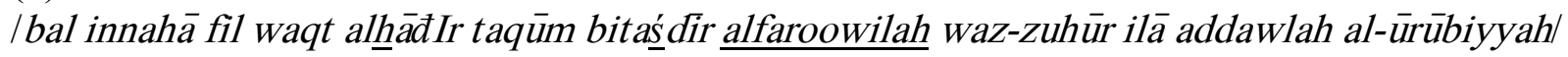

$$
\text { بل إنها في الوقت الحاضر تقوم بتصدير الفراولة والزهور إلى الدولة الأوروبية. }
$$

'Negara tersebut, pada masa mendatang akan mengekspor strawberi dan bunga ke negara-negara Eropa'

(2)

/ kamā tūjad fī sūriyah al-amākin wal kanā?Is allatī tạhadda șa 'anhā al-injīill

$$
\text { كما توجد في سورية الأماكن والكنائس التي تحدث عنها الإنجيل. }
$$

'sebagaimana di Suria terdapat tempat-tempat dan gereja-gereja yang dibicarakan oleh Injil'

$(3)^{*}$

/irtabaTOt 'ilāqotu indūnīsiyyā ma'a dawlah mātiziya munðu/*

* ارتبطت علاقة إندونيسيا مع الدولة الماليزية منذ

'Hubungan Indonesia dan Malaisyia terjalin $\underline{\text { sejak }}^{*}$

$(4)^{*}$

/ adn alharokah at-tijäriyyah ad-dāiroh mina-l fajr hatttā al-fajr/*

عدن الحركة التجارية الدائرة من الفجر حتى الفجر

'Aden gerakan perdagangan yang terus menerus berlangsung mulai fajar sampai fajar'*

Satuan-satuan kebahasaan di atas diidentifikasi mahasiswa sebagai konteks yang mewadai kata yang sulit (bergaris bawah). Konteks yang utuh terdapat pada contoh (1) dan (2) Keduanya merupakan klausa dan mengandung semua unsur kelengkapan frasa yang diperlukan. Berbeda dengan itu, contoh (3) dan (4) merupakan contoh konteks yang tidak utuh. Contoh (3) sebetulnya merupakan klausa dengan unsur pokok / 'ilāqOtu indūnísiyyā ma'a dawlah mātiziya / sebagai S dan /irtabaTOt / sebagai P. Konteks ini menjadi tidak utuh karena mahasiswa menyertakan kata /munðu/ 'sejak' yang merupakan unsur pembentuk keterangan waktu, tetapi waktu yang dimaksudkan tidak disertakan. Hal itu justru mengindikasikan kurangnya pemahaman mahasiswa terhadap keutuhan konteks tersebut atau bahkan kurangnya pemahaman terhadap kalimat itu.

Berbeda dengan itu, ketidakutuhan konteks pada contoh (4) tampak jelas dengan tidak adanya unsur P pada satuan tersebut. Contoh (4) tersebut diawali dengan nama kota atau teluk 


\section{Arabi : Journal of Arabic Studies}

Aden sebagai $\mathrm{S}$ dan diikuti frasa / alharOkah at-tijāriyyah ad-dāirOh mina-l fajr hattāal-fajrl dan diduga sebagai unsur O. Keberadaan $\mathrm{O}$ pada contoh (4) tersebut seharusnya didahului oleh unsur $\mathrm{P}$ transitif. Dengan demikian, ketiadaan unsur $\mathrm{P}$ merupakan menyebab ketidakutuhan satuan pada contoh 4.

Berikut ini empat contoh hasil identifikasi makna kata dalam konteks; dua yang pertama berkategori akurat dan dua yang terakhir tak akurat.

(5)

[YOrsu] غرس 'penanaman'

[qOd tamma YOrsu mā yuqO:ribu min 130 milyūn SajarOh]

قد تم غرس ما يقارب من · ب ا مليون شجرة

'telah selesai dilakukan penanaman \pm 130 juta pohon'

(6)

[an-na) id alwat'Oniy] النشيد الوطني 'lagu kebangsaan'

[an-na/ïd alwat' Oniy alhāliy bada?a istixdāmuhu fĩ 25 fabrO:yir 1978]

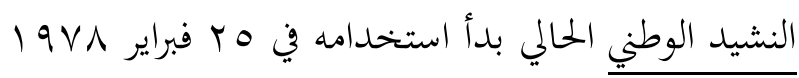

'lagu kebangsaan yang sekarang telah mulai digunakan pada 25 Februari 1978,

(7)

lat-taświt| التصويت 'teriakan'*

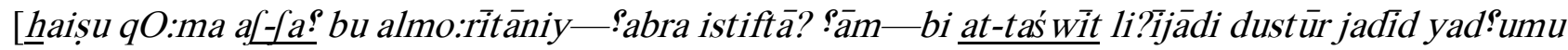
intixO:bät al-ahzāb]

$$
\text { حيث قام الشعب الموريتاني عبر استفتاء عام بالتصويت لإيجاد دستور جديد يدعم انتخابات الأحزاب }
$$

'masyarakat Moritania melaksanakan teriakan melalui referendum untuk menghasilkan perundangan baru yang mendukung pemilihan partai politik'*

(8)

[alhāmmah] الهامة 'pemimpin kaum'*

[wakaðālika assiyāhahah addīniyyah min jawāmI’ wa masajId tārixixyyah wa al-maqO:māt wa almazārO:t addiniyyah al-hāmmah]

$$
\text { وكذلك السياحة الدينية من جوامع ومساجد تاريخية والمقامات والمزارات الدينية الهامة }
$$

'Demikian halnya wisata religius, misalnya masjid jami' bersejarah, makam, dan tujuan wisata para pemimpin kaum*.

Pada setiap satuan di atas terdapat satu kata yang dianggap sulit, yaitu kata [YOrs], [anna/ìd alwat'Oniy], [at-taświt] , dan [alhämmah]. Kata [YOrs] dan [an-na/ïd alwat'Oniy] dimaknai 'penanaman' dan 'lagu kebangsaan'. Dengan makna tersebut, satuan (5) dan (6) dapat dipahami dengan mudah. Hal itu menunjukkan bahwa identifikasi makna kedua kata sulit tersebut dilakukan secara akurat. Berbeda dengan itu, kata [at-taświt] dan [alhämmah] pada satuan (7) dan (8) dimaknai 'teriakan' dan 'pemimpin kaum'. Makna tersebut tidak sesuai dengan konteks kalimat yang mewadai kata sulit itu. Kata [at-taświt $]$ merupakan bentuk verba dari kata $[\underline{s} O w t]$ yang bermakna 'suara'. Adapun tema dalam konteks satuan itu adalah kegiatan referendum dalam rangka pembentukan undang-undang dasar yang baru. Berkaitan dengan tema tersebut, makna yang tepat dari kata [at-taświt] adalah 'pemberian suara'. Dengan makna tersebut, satuan di atas dapat dipahami bahwa rakyat Mouritania memberikan hak suara mereka dalam referendum pembentukan undang-undang dasar yang baru yang mendukung pelaksanaan pemilu multipartai. 
Topik yang dibicarakan pada satuan kebahasaan (8) adalah tentang tempat wisata religi, baik berupa masjid bersejarah, pemakaman, dan lainnya. Pemaknaan [alhämmah] dengan makna 'pemimpin kaum' memiliki korelasi dengan tema yang dibicarakan, tetapi makna tersebut tidak sesuai dengan jenis frasa atributif yang terbentuk dengan kata [alhämmah] itu. Dalam hal ini, kata [alhāmmah] merupakan unsur ajektifa atau atribut dari unsur pokok frasa, yaitu [al-maqO:māt] dan [al-mazārO:t]. Sebagai atribut, kata [alhāmmah] tentu mengandung makna atribusi, yaitu 'penting'. Jika benar bahwa kata / alhāmmah / memiliki makna leksikal 'pemimpin kaum', dalam arti makam para pemimpin kaum, maka kata [alhämmah] seharusnya dikonstruksikan ke dalam frasa idhafah, karena frasa idhafah cenderung mengandung makna kepemilikan (Schulz, 2009).

\section{Pola Hubungan Penggunaan Strategi, Keutuhan Konteks, dan Akurasi Makna}

Tingkat akurasi makna yang diidentifikasi dengan menggunakan lima jenis strategi tersebut cukup bervariasi. Penggunaan kamus online mempunyai tingkat akurasi tertinggi $81.48 \%$ dari 108 pengoperasian, diikuti kamus cetak $74.85 \%$ dari 163 pengoperasian, dan kamus digital $68.54 \%$ dari 321 pengoperasian. Penggunaan strategi bertanya kepada teman dan pemanfaatan konteks yang keduanya mempunyai frekuensi penggunaan yang relatif rendah $(3.4 \%)$ dan $(0.65 \%)$ ternyata juga memiliki akurasi yang rendah pula, yaitu 50\% atau bahkan kurang. Grafik 04 berikut memberikan gambaran yang lebih visual tentang persentase penggunaan strategi dan persentase akurasinya.

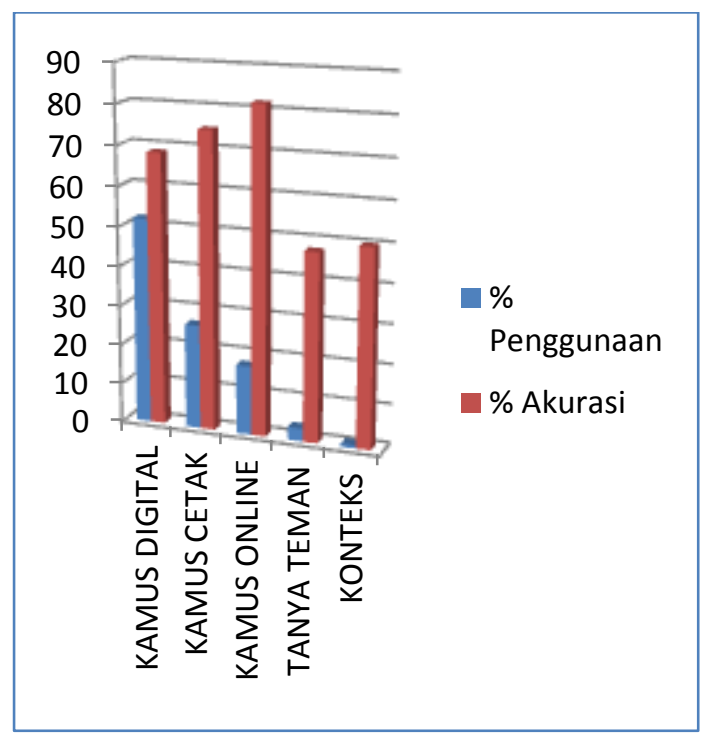

Grafiks 04: Penggunaan Strategi dan Akurasinya

Hubungan antar keutuhan konteks dan akurasi makna memiliki empat kategori, yaitu a) konteks utuh dan makna akurat (U-A), b) konteks utuh tetapi makna tidak akurat (U-TA), c) konteks tidak utuh tetapi makna akurat (TU-A), dan d) konteks tidak utuh dan makna tidak akurat (TU-TA). Di antara empat kategori tersebut yang memiliki kecenderungan tertinggi adalah kategori U-A (64.18\%) diikuti kategori U-TA (23.18\%), lalu TU-A (7.46\%), dan terkecil TU-TA $(5.19 \%)$. 


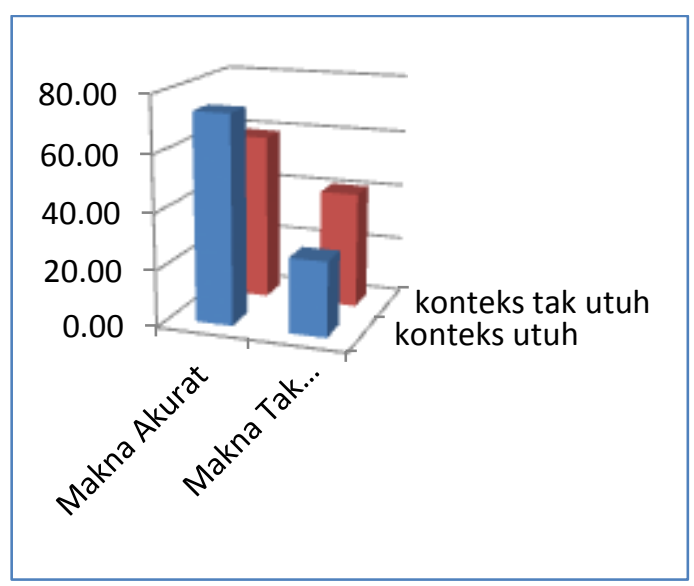

Grafik 05: Perbandingan Akurasi Makna pada Konteks yang Utuh dan Tidak Utuh Grafik 05 menunjukkan bahwa identifikasi makna kata secara akurat lebih besar daripada identifikasi makna yang tidak akurat baik pada konteks yang utuh maupun tidak utuh. Identifikasi makna secara akurat pada konteks yang utuh lebih besar daripada pada konteks yang tidak utuh. Sebaliknya, identifikasi makna secara tidak akurat pada konteks yang tidak utuh lebih besar daripada pada konteks yang utuh.

(9) [ittifāqiyāt] تاتفات 'perjanjian'

[tahasśs Olat mo:rìtāniyā ?alājuz?In min aśś OhrO:?_alYOrbiyyah ba?da ittifāqiyāt madrìd]

$$
\text { تحصلت موريتانيا على الجزء من الصحراء الغربية بعد اتفاقيات مدريد }
$$

'Moritania memperoleh sebagian wilayah Sahara Barat setelah perjanjian Madrid'

[?ahd] عهt 'perjanjian'* $\rightarrow$ 'masa'

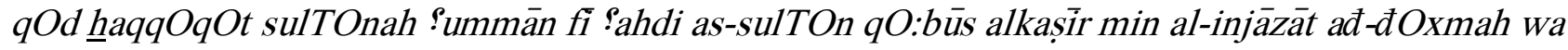
fì käffati-1 majālät

$$
\text { قد حققت سلطنة عمان في عهد السلطان قابوس الكثير من الإبحازات الضخمة وفي كافة المجالات. }
$$

'Kesultanan Oman pada perjanjian Sultan Qabus telah mencapai keberhasilan dalam berbagai bidang'* $\rightarrow$ 'masa'

[al-aqOlliyah] الأقلية 'minoritas'

[rO?is al-aqOlliyah alkurdiyyah]

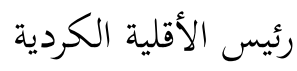

'pimpinan kelompok minoritas Kurdi'

[taxTit] تخطيط 'garisan/ukuran'* $\rightarrow$ 'penentuan'

[tahlid wa taxTīT alhudūd]

تحديد وتخطيط الحدود

'garisan/ukuran perbatasan'* $\rightarrow$ 'penentuan'

Keutuhan konteks dan akurasi makna terdapat pada contoh nomor (9) berupa klausa yang terdiri atas tiga unsur, yaitu S [mauritania], P [tahasśśSlat ?alā juz?In min aśś Oh̆rO:? 
alYOrbiyyah], dan K [båda ittifäqiyāt madrid]. Ketiga unsur klausa tersebut terbentuk oleh unsur-unsur pembentuk frasa secara lengkap. Pada satuan tersebut, kata yang dipandang sulit adalah [ittifáqiyāt] yang dimaknai'perjanjian'. Makna tersebut akurat untuk diterapkan pada kata dan konteksnya. Dengan demikian, satuan tersebut merupakan konteks yang utuh bagi kata sulit yang dimaksudkan dan makna kata sulit yang diidentifikasi pun akurat.

Satuan kebahasaan nomor (10) juga merupakan konteks yang utuh bagi kata [?:ahd] yang dipandang sulit oleh mahasiswa. Satuan tersebut berupa kalimat dengan satu klausa yang terbentuk oleh unsur SPOK. Keempat unsur tersebut adalah [sulTOnah ?ummān] sebagai S, /

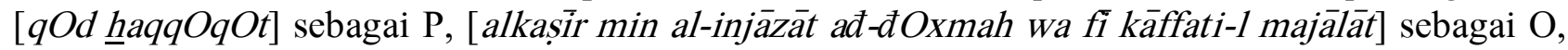
dan [fî̀ ?ahdi as-sulTOn $q O: b \overline{u s}]$ sebagai K. Pada satuan tersebut semua komponen frasa utuh sehingga tidak menimbulkan gangguan makna. Dalam hal ini, gangguan makna justru terjadi akibat kesalahan identifikasi makna kata sulit. Kata [?ahd] paling tidak memiliki dua alternatif makna, yaitu 'masa' dan 'perjanjian'. Pada konteks satuan nomor (10), makna yang tepat untuk kata [?ahd] adalah 'masa', sehingga dapat dipahami bahwa kemajuan besar pemerintahan Kesultanan Oman di berbagai bidang terjadi pada masa pemerintahan Sultan Qabus. Berbeda dengan itu, mahasiswa memilih makna 'perjanjian', sehingga satuan yang dimaksud tidak bisa dipahami.

Satuan nomor (11) tidak mengandung P. Karena itu, satuan tersebut tidak menjadi konteks yang utuh bagi kata sulit/al-aqOlliyah/. Satuan tersebut berupa tataran frasa idhafah /rO?isu-l aqOlliyah/ 'kepala kelompok minoritas' dan frasa ajektifal /al-aqOlliyah al-kurdiyyah/ 'minoritas Kurdi'. Fungtor yang ditempati oleh satuan itu pun tidak jelas, apakah sebagai S, P, atau O.

Satuan kebahasaan nomor (12) merupakan contoh satuan yang tidak utuh sebagai konteks kata sulit yang terkandug di dalamnya sekaligus identifikasi maknanya tidak akurat. Tidak utuh karena tidak berupa klausa, melainkan berupa gabungan dari frasa koodinatif [tahdid wa taxTíT] dan frasa idhafah [taxTiT allhudūd. Identifikasi mana kata sulit pada satuan itu pun tidak akurat. Kata [taxTiT] dimaknai 'garisan" atau "ukuran". Makna tersebut tidak akurat, karena yang dimaksudkan dengan [taxTiTT] pada satuan ini adalah 'penentuan/penetapan'. Frasa [tahdid

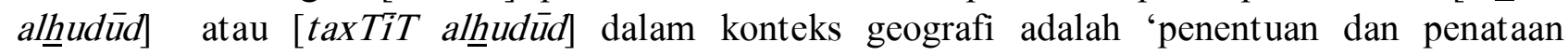
perbatasan'.

\section{PEMBAHASAN}

\section{Variasi Strategi Identifikasi Makna Kata}

Temuan penelitian ini relevan dengan cara mengembangkan kosakata secara sistematis yang dikemukakan Kinsella et al (2002), yaitu pemanfaatan kamus, penggunaan kata di dalam kalimat, pemerhatian konteks, dan penghapalan definisi. Empat cara yang dikemukakan Kinsella tersebut dapat diklasifikasi menjadi dua, yaitu cara menemukan makna kata dan cara merawat kata yang telah dipelajari. Pemanfaatan kamus dan pemerhatian konteks merupakan strategi menemukan makna kata. Strategi penggunaan sumber yang ditempuh oleh pembelajar Indonesia untuk menemukan makna kata bahasa Arab tidak lain adalah penggunaan kamus, baik kamus cetak, kamus digital, atau bahkan kamus online. Penggunaan kamus untuk menemukan makna kata juga direkomendasikan oleh Hunt dan Beglar (2005) dalam tulisannya berjudul A Framework for Developing EFL Reading Vocabulary. Penggunaan kamus menurut Hunt dan Beglar (2005) termasuk salah satu strategi belajar dan mengajar kosakata secara eksplisit.

Hasil penelitian menunjukkan dominasi penggunaan kamus dua bahasa terhadap kamus satu bahasa dengan perbandingan 8:1. Hal itu dapat dipahami karena kemampuan mahasiswa Jurusan Sastra Arab termasuk kateori menengah ke bawah. Thomson (1978 dalam Berrabah, 2014) mengemukakan bahwa untuk pembelajar menengah, kamus dua bahasa lebih menguntungkan daripada kamus satu bahasa. Sebaliknya, bagi pembelajar tingkat lanjut kamus satu bahasa lebih menguntungkan. Lebih Lanjut Berrabah (2014) menjelaskan bahwa bagi pemula, kamus dua bahasa merupakan sumber informasi yang sangat efektif dan memicu motivasi. Mahasiswa mudah 


\section{Arabi : Journal of Arabic Studies}

menemukan makna dengan bertolak pada kata dalam bahasa pertamanya. Sebaliknya, kamus dua bahasa mendorong pemula untuk kecenderungan menerjemahkan, mengaitkan kata perkata dalam dua bahasa, dan kurang memadai dalam mendeskripsikan perilaku sintaktik kata.

Di sisi lain, dominasi penggunaan kamus digital terhadap penggunaan kamus cetak ataupun online bisa dipahami karena penggunaan kamus digital lebih praktis. Mahasiswa pada umumnya selalu membawa laptop bahkan HP android yang dilengkapi dengan software kamus digital. Dengan demikian, mereka tidak perlu repot membawa kamus cetak yang justru membebani fisik mereka. Penggunaan kamus digital pun lebih mudah, karena pengguna tinggal menulis kata yang dimaksudkan dan makna dari kata itu pun langsung keluar. Jadi pengguna tidak perlu memikirkan akar kata dari kata sulit yang dikehendaki.

Meskipun demikian, dalam hal ini, ketika mereview tugas mahasiswa di awal setiap perkuliahan, dosen sering menagaskan agar mahasiswa lebih banyak menggunakan kamus cetak dan berhati-hati dalam penggunaan kamus digital dan online, karena makna yang dihadirkan seringkali terlepas dari konteks. Dengan kata lain, makna yang dihadirkan oleh kamus digital dan kamus online seringkali makna harfiah yang tidak selalu sesuai dengan konteks kalimat yang mengandung kata yang dimaksud. Berbeda dengan itu, jika subjek menggunakan kamus cetak, ia dapat memilih makna yang lebih sesuai dengan konteks kalimatnya. Di dalam kamus cetak, biasanya disediakan beberapa makna beserta contoh konteks kalimatnya, sehingga pembaca dapat memilih makna yang dimaksudkan berdasarkan kemiripan konteks kalimat yang mengandung kata sulit tersebut dengan konteks kalimat pada kamus. Lebih dari itu, dosen sering mengingatkan bahwa penggunaan kamus digital (atapun kamus online) dikhawatirkan dapat menurunkan penguasaan mahasiswa terhadap sistema derivasi kata bahasa Arab.

Selain penggunaan kamus, yang termasuk strategi belajar dan mengajar kosakata secara eksplisit menurut Hunt dan Beglar (2005) adalah menginferensi berdasarkan konteks. Menginferensi berdasarkan konteks bisa dilakukan jika pembelajar memperhatikan dengan teliti dan cermat konteks yang mewadahi suatu kata, sehingga dapat menebak atau menyimpulkan makna kata yang dimaksudkan. Hal itu berarti strategi mengiferensi berdasarkan konteks yang dimaksudkan oleh Hunt dan Beglar pada dasarnya sama dengan strategi memperhatikan konteks yang dikemukakan oleh Kinsella et al (2002). Strategi tersebut tidak lain merupakan penebakan makna kata dengan memperhatikan kata-kata yang berhubungan atau konteks kata tersebut.

Dalam hal ini, Cahyono (1993) juga menempatkan penggunaan kamus pada urutan pertama dari lima cara mengembangkan kosakata. yaitu a) pemakaian kamus, b) pembuatan catatan kata, c) penggunaan sarana penghafal, d) mempelajarai kata-kata yang berhubungan, dan e) tebakan cerdik (educated guessing). Sebaliknya, penebakan secara cerdik ditempatkan pada urutan terakhir. Di sisi lain, temuan tentang kurang dioperasikannya strategi konteks secara tidak langsung semakin mendukung usulan Nation (2001) tentang perlunya pelatihan strategi belajar, khususnya untuk mengatasi kesulitan yang disebabkan oleh kurangnya kosakata. Hal itu berarti keterampilan mengidentifikasi atau menemukan makna kata BA sangat penting untuk dikembangkan. Guru/dosen BA tidak saja perlu mengajarkan kosakata, melainkan juga perlu melatihkan strategi atau cara-cara tertentu untuk mengidentifikasi makna kata dalam konteks.

\section{Hubungan Strategi, Keutuhan Konteks, dan Akurasi Makna Kata}

Sebagaimana dikemukakan pada bagian hasil, kemampuan mahasiswa mengidentifikasi keutuhan konteks relative tinggi dengan indeks skor 87.36. Kemampuan mengidentifikasi makna dalam konteks secara akurat juga relatif tinggi yaitu dengan indeks $71.64 \%$. Identifikasi makna secara akurat pada konteks yang utuh lebih besar daripada pada konteks yang tidak utuh. Sebaliknya, identifikasi makna secara tidak akurat pada konteks yang tidak utuh lebih besar daripada pada konteks yang utuh.

Temuan ini sesuai hasil penelitian Dash (2008) bahwa subjek penelitiannya (penutur bahasa Banggali) mampu mengidentifikasi makna kata melalui konteks local yang minimal terdiri atas

Vol. 1 No. $2 \mid 20-23$

Copyright @ 2016 | ARABI | p-ISSN 2548-6616 | e-ISSN 2548-6624 
lima kata, dengan posisi kata yang ditargetkan berada di tengah. Artinya, subjek penelitian memperhatikan konteks atau lingkungan lingual minimal dua kata ke arah kiri dan dua kata ke arah kanan dari kata target. Hal itu menunjukkan bahwa semakin luas konteks atau lingkungan yang diperhatikan, subjek semakin mudah mengidentifikasi makna kata yang ditagetkan. Dash (2008) menegaskan bahwa di dalam penggunaan konteks kalimat, subjek dituntut untuk menemukan kata yang memiliki hubungan semantik yang spesial dengan KK. Karena itu, jika konteks kalimat yang diidentifikasi atau diperhatikan oleh subjek tidak utuh terlebih lagi tidak mengandung predikat atau subjek, subjek cenderung gagal mengidentifikasi makna kata.

Dalam hal akurasi makna, hasil penelitian ini berbeda dengan temuan Nassaji dalam Mohebbi (2013). Sebagaimana dikutip Mohebbi, Nassaji meneliti penggunaan strategi dan sumber pengetahuan dalam melakukan inferensi makna kata dan hubungannya dengan kesuksesan dalam penggunaan strategi tersebut. Nassaji menemukan bahwa tingkat kesuksesan mereka rendah meskipun pembelajar B2 menerapkan strategis dan sumber pengetahuan yang dapat mereka akses. Perbedaan ini dapat dijelaskan dari dua sisi. Pertama, strategi menemukan makna yang diteliti Nassaji terbatas pada strategi inferensi atau menebak makna. Kedua, berbalikan dengan itu, meskipun dalam penelitian ini, strategi yang diteliti lebih bersifat umum, kenyataannya mahasiswa kurang mengoperasikan strategi memanfaatkan konteks atau menebak makna.

Selain berbeda frekuensi penggunaannya, strategi-strategi yang digunakan mahasiswa dalam mengidentifikasi makna kata juga memiliki indeks akurasi yang berbeda. Strategi bertanya kepada teman dan memanfaatkan atau menebak sesuai konteks sangat jarang dioperasikan (3.4\%) dan $(0.65 \%)$ sekaligus memiliki akurasi yang rendah pula, yaitu $50 \%$ atau bahkan kurang.

Mohebbi (2013) juga mengutip penelitian lain dari Nassaji (2004) tentang hubungan kedalaman pengetahuan kosakata pembelajar B2 dan penggunaan strategi inferensi leksikal serta kesuksesannya. Ia menemukan bahwa pembelajar yang memiliki pengetahuan kosakata B2 yang lebih kuat cenderung lebih banyak menerapkan strategi infereksi leksikal tertentu. Ditemukan bahwa kedalaman pengetahuan kosakata B2 sangat penting dalam kesuksesan inferensi leksikal. Hu dan Nation (2003 dalam Berrabah, 2014) mengemukakan bahwa untuk dapat menerka makna kata secara akurat dari konteks dalam rangka memahami suatu teks, seseorang perlu memiliki 95\% kosakata dalam teks.

Akurasi dalam identifikasi makna kata melalui kamus cetak relatif kurang optimal (74.85\%). Hal itu dapat dipahami karena mahasiswa memang kurang mengoperasikan strategi konteks (tidak lebih dari $0.81 \%$ ). Di sisi lain, mahasiswa kurang cermat dan cenderung tergesa-gesa dan mengambil makna atau arti dalam kamus. Lebih dari itu, kamus-kamus cetak tertentu tidak menyajikan konteks atau tidak memasukkan kata kedalam kalimat.

Ketergesaan maksudnya begitu menemukan kata yang dimaksudkan pada suatu halaman kamus, mahasiswa langsung mengambil makna atau arti kata yang tertulis di sebelahnya tanpa memperhatikan kesesuaiannya dengan konteks. Sebagai contoh, ketika mencari dan menemukan kata [؟ahdUn] dalam kamus Mahmud Yunus (Yunus, 1989), mahasiswa langsung mengambil makna 'janji' yang memang tertulis di deretan awal, tanpa memperhatikan kesesuaiannya dengan konteks. Padahal di deretan bawahnya tertulis makna 'masa' yang lebih sesuai dengan konteks.

Kesalahan dalam mengidentifikasi makna kata dari kamus cetak juga disebabkan oleh kekurangcermatan dalam membaca teks dan kurangnya perhatian terhadap konteks pembicaraan. Sebagai contoh, ketika menemukan kata [البطالة] dalam suatu satuan kebahasaan dengan topik kalimat tentang penciptaan lapangan kerja, ia membacanya [bat'O:lah] dengan vokal [a] di belakang [b]. Dengan pelafalan itu, kata tersebut bermakna 'kepahlawanan' yang tidak sesuai dengan topik tuturan. Selain dibaca [bat'O:lah] dengan vokal [a] pada [ba], kata yang dimaksud bisa dibaca [bit'O:lah] dengan vokal [i] di belakang [b] dan memiliki makna 'pengangguran'. Makna ini lebih signifikan dan relevan dengan topik yang dibicarakan yaitu pembukaan lapangan kerja untuk mengurangi angka pengangguran akibat krisis politik. 


\section{Arabi : Journal of Arabic Studies}

\section{Simpulan}

Berdasarkan hasil penelitian dapat disimpulkan sebagai berikut: 1) mahasiswa pada umumnya menggunakan kamus dua bahasa (kamus digital, kamus cetak, kamus online) dan sedikit menggunakan strategi bertanya kepada teman dan ataupun memanfaatkan konteks; 2) mahasiswa memiliki kemampuan yang tinggi dalam mengidentifikasi konteks yang utuh dan mengidentifikasi makna kata sulit secara akurat; 3) penggunaan kamus digital-frekuensi tertinggi-tidak otomatis diikuti akurasi tertinggi pula; sebaliknya strategi bertanya dan strategi konteks yang kurang digunakan memiliki akurasi yang rendah pula; adapun penggunaan kamus online mempunyai tingkat akurasi tertinggi, 4) kemampuan mengidentifikasi keutuhan konteks lebih mendukung dalam mengidentifikasi makna secara akurat.

Penelitian ini memberikan rekomendasi sebagai berikut: 1) mahaiswa perlu lebih memperhatikan relevansi makna kata yang diambil dari suatu kamus dengan konteks pembicaraan dan lebih memperhatikan keutuhan konteks, 2) para dosen hendaknya melatihkan keterampilan (a) menemukan makna kata yang relevan dengan konteks melalui kamus cetak dan digital, (b) mengidentifikasi makna kata sulit berbasis konteks, dan (c) mengenali keutuhan konteks, dan 3) pimpinan Jurusan Sastra Arab perlu memprogramkan peningkatan keterampilan mahasiswa dalam menggunakan kamus untuk menemukan makna kata yang relevan dengan konteks. []

\section{Daftar Rujukan}

Asrori, Imam. 2007. Pengembangan Kemahiran Berbicara Arab oleh Mahasiswa Penutur Bahasa Indonesia dalam Perspektif Strategi Belajar Bahasa. Disertasi Tidak Diterbitkan. Malang: PPS Universitas Negeri Malang.

Bengeleil, Nazmia F dan Paribakht, T. Sima. 2004. L2 Reading Proficiency and Lexical Inferencing by University EFL Leaners. The Canadian Modern Language Review. Vol. 61, No. 2, (December): 225-249.

Berrabah, Boumediene. 2014. Developing Vocabulary Through The Receptive Skills: Case of $1^{\text {st }}$ Year EFL Students at The University of Tlemcen. Online. Akses tanggal 20 Januari 2016. http://dspace.univ-tlemcen.dz/bitstream/112/7753/1/benrabah-boumediene.pdf

Cahyono, B.Y. 1993. Pengaruh Pengajaran Kosakata Topikal pada Peningkatan Penguasaan Kosakata bahasa inggris. Bahasa dan Seni Vol. XXI No 2 Agustus 1993. hlm 54-63

Dash, Niladri Sekhar. 2008. Context and Contextual Word Meaning dalam SKASE Journal of Theoretical Linguistics [online]. 2008, Vol. 5, No. 2. Available on web page http://www.skase.sk/Volumes/JTL12/pdf_doc/2.pdf. ISSN 1339-782X. Akses 26 Januari 2016.

Dzulkifli, Hidayatul Hasanah dan Musthafa, Nik Hanan. (2011). Istiraijiyyah Takhmin Ma'aniy Al-Mufrodat fil Qira'ah: Dirosah Muqaranah bayna At-Tasnifat Al-Muta'addidah. Annadwah Addawliyah hawla Tajribah Ta'limi Allughah Al Arabiyah fi Indunisiya. 16-18 Des 2011. Al-Barnamij Alkhash li Ta'limil Lughah Al-Arabiyah Jamiah Maulana malik Ibrahim Al-Islamiyah Al-Hukumiyah bi malang Indonnesia bit Ta'awuna ma Jam'iyyah adda'wah wa't Ta'lim fi Janub Syarq Asia.

Hunt, Alan dan Beglar, David. 2005. A Framework for Developing EFL Reading Vocabulary. Reading in a Foreign Language. Volume 17, No. 1, April 2005, ISSN 1539-0578.

Kinsella, Kate; Stump, Collen Shea; dan Feldman, Kevin. 2002. Strategies for Vocabulary Development. Online. http://www.phschool.com/eteach/language_arts/2002_03/essay.html. Akses: 16 Januari 2016.

Kweldju, Siusana. 2002. Pengajaran Bahasa Inggris Berbasis Leksikon: Sebuah Alternatif yang Tepat untuk Pengajaran Bahasa Inggris di Indonesia. Pidato Pengukuhan Guru Besar dalam

Vol. 1 No. 2 | 22-23

Copyright @ 2016 | ARABI | p-ISSN 2548-6616 | e-ISSN 2548-6624 
Arabi : Journal of Arabic Studies

Bidang Kosakata pada Fakultas Sastra, disampaikan pada Sidang Terbuka Senat Universitas Negeri Malang pada tanggal 3 Oktober 2002. Malang: Universitas Negeri Malang.

Mohebbi, Hassan. 2013. Investigating Vocabulary Learning in Second Language Classroom Context: Recent Finding, Future Outlook. Advances in Asian Social Science (AASS), Vol. 4, No. 3, 2013, ISSN: 2167-6429. Copyright (C) World Science Publisher, United States, www.worldsciencepublisher.org

Nation, I.S.P. 2001. Learning Vocabulary in Another Language. Cambridge: Cambridge University Press.

Schulz, Eckehard. 2009. Bahasa Arab Baku dan Modern: Allughah Al-Arabiyyah Al-Muasharah. Terjemah oleh Esie Hartianty-Hanstein dan Thoralf Hanstein. Yogyakarta: LkiS.

Yunus, Mahmud. 1989. Kamus Arab-Indonesia. Jakartā Hidakarya Agung. 